\title{
DESCRIPTIVE STATISTICS OF WORK ACCIDENTS IN BRAZILIAN WOOD PRODUCT MANUFACTURING
}

\author{
Pompeu Paes Guimarães ${ }^{1 *}$, Vinícius Gomes de Castro ${ }^{1}$, Flavio Cipriano de Assis do Carmo ${ }^{2}$, Kauê Augusto \\ Oliveira Nascimento ${ }^{3}$, Nilton Cesar Fiedler ${ }^{4}$, Renato Cesar Gonçalves Robert ${ }^{3}$ \\ ${ }^{1}$ Federal Rural University of the Semi-Arid, Center for Agricultural Sciences, Department of Agronomic and Forestry Sciences, Mossoró, \\ Rio Grande do Norte, Brazil, - pompeu.guimaraes@ufersa.edu.br; vinicius.castro@ufersa.edu.br \\ ${ }^{2}$ Federal University of Campina Grande, Patos, Rural Health and Technology Center Patos, Paraíba, Brazil - flavio.carmo@ufcg.edu.br \\ ${ }^{3}$ Federal University of Paraná, Department of Forestry and Wood Engineering, Curitiba, Paraná, Brazil - kaue.nascimento@ufpr.br; - \\ renatorobert@ufpr.br \\ ${ }^{4}$ Federal University of Paraná Espírito Santo, Department of Forestry Engineering, Jerônimo Monteiro, Espírito Santo, Brazil - \\ fiedler@pq.cnpq.br
}

Received for publication: 31/07/2019 - Accepted for publication: 25/01/2021

\begin{abstract}
Resumo
Estatísticas descritivas dos acidentes de trabalho na produção madeireira. A produção madeireira possui atividades perigosas e com elevada ocorrência de acidentes do trabalho. $\mathrm{O}$ objetivo do artigo foi analisar os acidentes de trabalho, registrados e não registrados, os tipos mais frequentes e a taxa de aumento nas diferentes atividades da produção madeireira. Foram contabilizados os acidentes totais, somatório entre os acidentes não registrados e registrados, e classificados como típicos, de trajeto e doenças do trabalho. A produção madeireira foi subdividida em serraria, fabricação de madeira laminada e de chapas de madeira compensada, prensada e aglomerada, e fabricação de móveis com predominância de madeira. A produção madeireira apresentou 2.849.470 empregos diretos. Para a atividade de fabricação de móveis houve um aumento na taxa de crescimento dos empregos diretos. No entanto, apresentou também um maior número de acidentes totais e uma elevação na taxa de crescimento do número de acidentes. Para a serraria e a fabricação de madeira laminada e chapas houve redução na taxa dos empregos diretos e dos acidentes ocorridos. Do total de acidentes mais de $20 \%$ não foram notificados. O principal tipo foi o típico (88,3\%), seguido pelos acidentes de trajeto $(9,5 \%)$ e doenças do trabalho $(2,1 \%)$.

Palavras-chave: segurança do trabalho; qualidade; cadeia produtiva
\end{abstract}

\section{Abstract}

Wood product manufacturing involves many dangerous activities and a high incidence of work-related accidents. The objective of this study was to analyze registered and unregistered work accidents, as well as the most frequent type and rate increase over the years for different activities of wood product manufacture in Brazil. Total accidents were counted including both unregistered and registered accidents. The accidents were classified as either a typical accident, a commuting accident or occupational diseases. Evaluated production was subdivided into sawmill operations, manufacture of laminated wood and plywood, wood-derived pressed and agglomerated sheets, and furniture with a predominance of wood. Wood production presented 2,849,470 direct jobs. For the furniture manufacturing sub-sector, there was an increase in the growth rate for direct jobs. However, there was a greater number of total accidents and an increase in the rate of number of accidents over time. For sawmills and the manufacture of laminated wood and slabs, there was a decreasing trend in the rate of direct jobs and accidents. Of the total number of accidents, more than $20 \%$ were not reported. The primary accident incidence was the typical accident (88.3\%), followed by commuting accidents $(9.5 \%)$ and lastly occupational diseases $(2.1 \%)$.

Keywords: occupational safety; quality; supply chain.

\section{INTRODUCTION}

The wood products sector produced a gross revenue of R \$ 97.4 billion in 2019 (1.2\% of the National GDP) and generated 3.75 million direct jobs (IBA, 2020). However, this sector also has one of the highest rates of accidents, occupational diseases and early retirements (SAFETY AND HEALTH IN FOREST WORK: CODE OF PRACTICES OF ILO, 2021). Wood products manufacture also showed the highest mortality rates associated with work and even after the training and identification of risks, the number of accidents that occurred were not reduced (ASSUNÇÃO and CAMARA, 2011).

Wood manufacture brings together a series of dangerous activities and exposes its workers to various physical, chemical, biological, ergonomic and accident risks (MENDOZA and BORGES, 2016). Wood manufacture together with the civil construction and petrochemical sectors constitute in themselves the most dangerous industrial activities in Brazil, with most accidents that occur being unknown (MEDEIROS and JURADO, 2013). Wood manufacturing generates dust that is allergic to the skin, can cause conjunctivitis and 
respiratory problems, in addition to the risk of exposure to excessive noise, hearing loss and musculoskeletal damage resulting from physical overload of workers (OLIVEIRA JUNIOR et al., 2014).

The Brazilian Standard NR-31 (2020) that deals with Safety and Health at Work in Agriculture, Livestock, Forestry and Aquiculture has recently been changed and involves issues of obligations and competency. This standard provides information about the risk management program, specialized services in health and safety at work, the internal commission for the prevention of rural work accidents, as well as measures to establish guidelines to be observed in the organization and in the rural work environment, in order to make the planning and development of the sector's activities compatible with the prevention of accidents and related diseases in rural work.

Occupational accidents are a Brazilian social and economic problem, in addition to other expenses, which are destined for the health sector, such as hospital medical care for victims of wood production accidents, the negative impact on lives of workers and their families. (ULTRAMARI et al., 2012). When communicating workrelated accidents at work, it is possible to compile a statistical and historical data record of the company about accident rates, and through this, to analyze the factors associated with it (SOUSA et al., 2010). The objective of this article was to analyze the historical data of Brazilian work accidents, registered and unregistered, as well as the most frequent types and rates of increase for the different activities of wood product manufacturing sector.

\section{MATERIAL AND METHODS}

Accidents in wood production were determined through social security records, during the period of 2006 to 2014 (SOCIAL SECURITY STATISTICAL YEARBOOK, 2017). The type of accidents analyzed were derivived from total accidents, including registered and unregistered accidents. The registered accidents were accidents with the Communication of Accidents at Work (CAT) and registration at the National Institute of Social Security (INSS), being subdivided into typical accidents - originating from the work activity performed by the worker; commuting accidents - during travel between the residence and the workplace, and vice versa - and occupational diseases - caused by any type of occupational disease peculiar to a particular sub-sector.

Wood product manufacturing is classified as sawmills; laminated wood and plywood, pressed and chipboard panel fabrication; and furniture construction with predominance of wood, involved in the following National Classification of Economic Activities and activities:

- Sawmills (16.10-2) - Manufacture of uncut raw wood (sawn) and re-sawed wood (planks, posts, boards, planed for boxes use, crates and the like); wooden floors and floor and ceiling boards; railwood ties; mineral wool and wood particles for any purpose; drying, preservation and immunization of wood; and wood waste briquettes (ecological charcoal);

- $\quad$ Laminated wood and panels of plywood, pressed and agglomerated (16.21-8) - Manufacture of laminated and veneered wood; sheets and plates of agglomerated or pressed wood, whether or not covered with plastic material; plywood sheets coated or not with plastic material; and densified wood (MDF);

- Furniture with predominance of wood (31.01-2) - Manufacture of wooden or predominantly wooden furniture, varnished, waxed, enamelled, lacquered, covered with sheets of plastic material, upholstered, for residential and non-residential use; wooden skeletons for furniture; inlaid wooden furniture; and finishing of furniture (varnishing, enamelling, lacquering and similar services).

For the three activities related to wood product manufacture, direct jobs from 2006 to 2014 were tabulated by the Brazilian Forest Service (SNIF 2017). Direct jobs and accidents at work were presented in the form of descriptive statistics for the activities that constitute wood product manufacture. Direct jobs and number of accidents for each activity were subjected to an analysis of variance in a completely randomized design and compared with Tukey's test at 5\% of significance level, when there were statistically significant differences. Trend models were adjusted to calculate the annual growth rates of direct jobs and accidents by wood manufacture subsector. Using the methodology of Almeida et al. (2009), Aguiar et al. (2014), and Guimarães et al. (2018) shown in Equations 1, 2 and 3:

$$
\operatorname{Ln} E=\beta_{0}+\beta_{1} T+\varepsilon(1) \quad \operatorname{Ln} A=\beta_{0}+\beta_{1} T+\varepsilon(2) \quad r=e\left(\beta_{1}-1\right) 100(3)
$$

where: $\mathrm{E}$ is the number of direct jobs in year $\mathrm{T}$; $\mathrm{A}$ is the number of accidents in year $\mathrm{T}$; $\mathrm{T}$ the independent variable, in years; $\varepsilon$ is the error term; and; $r$ is the composite growth rate. 


\section{RESULTS}

The wood product manufacture employeed 2,849,470 workers 2006 and 2014. The largest number of accidents occurred in the production of furniture. This sub-sector also had an increasing rate of accidents over the years (Table 1).

Table 1. Descriptive statistics for direct jobs and total accidents in wood manufacturing

Tabela 1. Estatísticas descritivas dos empregos diretos e acidentes totais da produção madeireira.

\begin{tabular}{|c|c|c|c|c|c|c|}
\hline & CNAE & Total & $\%$ & Mean & CV\% & Rate \\
\hline \multirow{4}{*}{$\begin{array}{c}\text { Direct } \\
\text { jobs }\end{array}$} & $16.10-2$ & 779,088 & 27.3 & $86,565.3 \mathrm{~b}$ & 10.0 & -3.28 \\
\hline & $16.21-8$ & 392,911 & 13.8 & $43,656.8 \mathrm{c}$ & 10.8 & -2.99 \\
\hline & $31.01-2$ & $1,677,471$ & 58.9 & $186,385.7 \mathrm{a}$ & 10.0 & 3.68 \\
\hline & Total & $2,849,470$ & 100 & & & \\
\hline \multirow{4}{*}{$\begin{array}{c}\text { Total } \\
\text { accidents }\end{array}$} & $16.10-2$ & 32,818 & 34.8 & $3,646.4 \mathrm{~b}$ & 17.20 & -5.82 \\
\hline & $16.21-8$ & 13,722 & 14.6 & $1,524.7 \mathrm{c}$ & 7.22 & -6.95 \\
\hline & $31.01-2$ & 47,755 & 50.6 & $5,306.1 \mathrm{a}$ & 8.80 & 0.68 \\
\hline & Total & 94.295 & 100 & & & \\
\hline
\end{tabular}

where: CV\% o Coefficient of Variation in percentage. Means followed by the same letter, in a column, within the same CNAE, do not differ at the $5 \%$ level of significance by the Tukey's test.

The Figure 1 indicates the trend of total accidents and direct jobs in wood manufacturing. The columns indicate total accidents and the dashed lines indicate direct jobs in wood manufacturing.

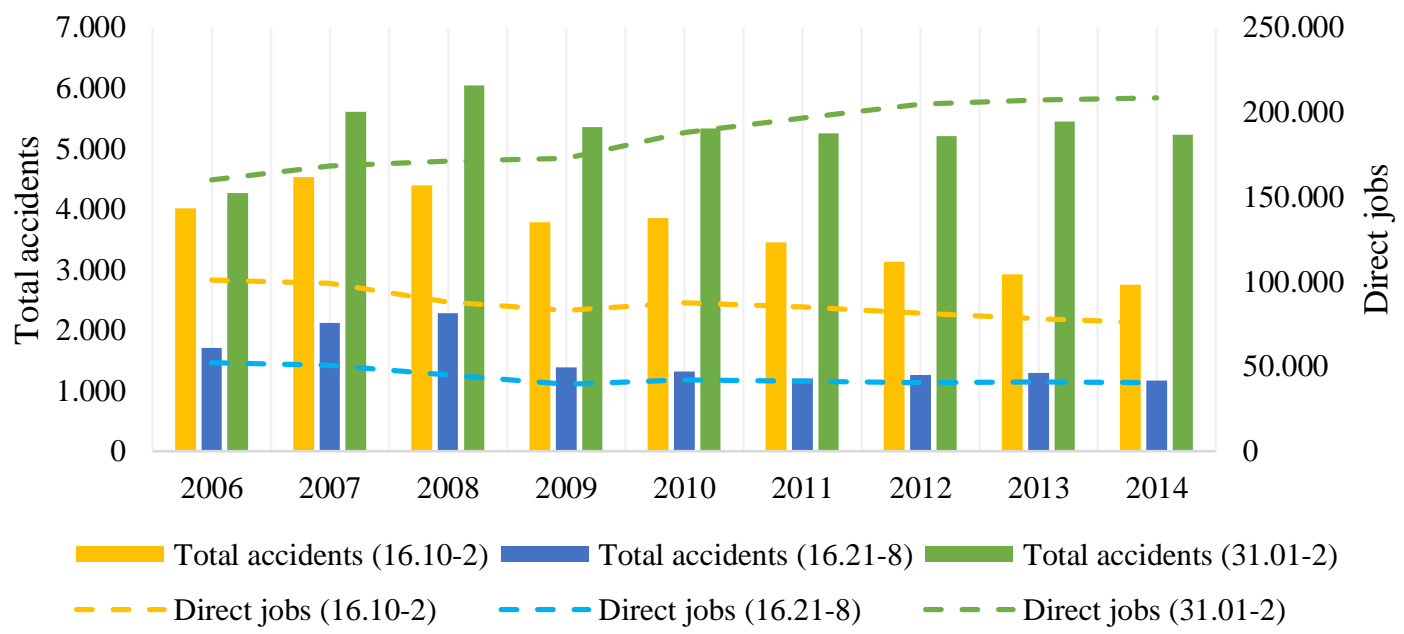

Figure 1. Trends of total accidents and direct jobs in wood manufacturing.

Figura 1. Tendência dos acidentes totais e empregos diretos na produção madereira.

A serious problem encountered in the wood product manufacturing sector was that most accidents were underreported, which hinders statistical analysis of this issue, as well as the prevention and control of the causes (MEDEIROS and JURADO, 2013). Thus, Table 2 shows the descriptive statistics of accidents not recorded in wood manufacturing.

Table 2. Descriptive statistics of accidents unregistered in wood product manufacturing.

Tabela 2. Estatísticas descritivas de acidentes não registrados na produção madeireira.

\begin{tabular}{cccccc}
\hline CNAE & Total accidents & Unregistered & $\%$ & Mean & CV\% \\
\hline $16.10-2$ & 28,802 & 7,236 & 25.1 & $904.5 \mathrm{~b}$ & 19.7 \\
$16.21-8$ & 12,021 & 3,341 & 27.8 & $417.6 \mathrm{c}$ & 32.3 \\
$31.01-2$ & 43,485 & 11,882 & 27.3 & $1,485.3 \mathrm{a}$ & 12.5 \\
\hline Total & 105,240 & 22,459 & 21.3 & & \\
\hline
\end{tabular}

Obs.: Observation period from 2007 to 2014. where: CV\% is Coefficient of Variation in percentage. Means followed by the same letter, in a column within the same code, do not differ at the 5\% level of significance by Tukey's test.

FLORESTA, Curitiba, PR, v. 51, n. 2, p. 339-345, abril/jun 2021.

Guimarães, P. P. et.al. 
In addition to the quantitative analysis, work-related accidents were described by type of occurrence, as typical accidents, commuting or illnesses related to work. Table 3 provides descriptive statistics for registered accidents, regarding the type of accidents in wood production.

Table 3. Descriptive statistics of registered accidents on type in wood product manufacturing. Tabela 3. Estatística descritiva dos acidentes registrados quanto ao tipo na produção madeireira.

\begin{tabular}{ccccc}
\hline CNAE & & Typical & Commuting & Occupational diseases \\
\hline & Total registered & 23,765 & 1,496 & 321 \\
$16.10-2$ & \% registered & 92.9 & 5.8 & 1.3 \\
& Mean & $2,640.6 \mathrm{~b}$ & $166.2 \mathrm{~b}$ & $35.7 \mathrm{a}$ \\
& CV\% & 24.5 & 13.7 & 41.8 \\
\hline \multirow{3}{*}{$16.21-8$} & Total registered & 9,426 & 791 & 164 \\
& \% registered & 90.8 & 7.6 & 1.6 \\
& Mean & $1,047.3 \mathrm{a}$ & $87.9 \mathrm{a}$ & $18.2 \mathrm{a}$ \\
& CV\% & 32.9 & 26.1 & 48.3 \\
\hline \multirow{3}{*}{$31.01-2$} & Total registered & 30,266 & 4,545 & 3.062 \\
& \% registered & 84.4 & 12.7 & $118.0 \mathrm{~b}$ \\
& Mean & $3,362.9 \mathrm{c}$ & $505.0 \mathrm{c}$ & 32.4 \\
\hline & CV\% & 7.6 & 14.7 & 1,547 \\
\hline
\end{tabular}

where: CV\% is Coefficient of Variation in percentage.

Means followed by the same letter, in a column within the same code, do not differ at the $5 \%$ level of significance by Tukey's test.

\section{DISCUSSION}

In 2012, the Brazilian Government gave incentives to increase competitiveness as an exemption from tax on the industrialized product (IPI), policies aimed at the housing sector and the increase in income for the Brazilian population contribute to the increase in demand for wood products (ABRAF, 2013).

The wood production activity that had the most employed workers in the last 8 years was the production of furniture, with more than $50 \%$ of direct jobs. It was also the only activity that showed a positive growth rate in the number of direct jobs. In a study on the status of wood processing companies in Minas Gerais State, Silva et. al (2011) observed that the jobs generated by this sector occurred in small and medium-sized companies and covered a small number of employees per company (68\% of them with up to five employees). Sawmill and sheet and laminate manufacture have shown a reduction in the number of direct jobs over the years (Table 1).

Furniture production, in addition to having a large number of direct jobs, also had an increasing rate in the number of accidents. The activities of sawmill and manufacture of laminated wood and panels, in addition to the reduction in the number of direct jobs, showed a decrease in the number of total accidents presented (Figure $1)$.

An analysis from 2008 to 2013 revealed that the wood products and paper industry was in tenth place for the economic sector in number of accidents, on average, with the highest recorded in 2013 (GUIMAR ̃̃ES et al., 2014). When analyzing the number of total accidents that occurred in wood products industry, the most unsafe activity was the manufacture of furniture, with an average of 5,306.1 accidents (Figure 1). That is, in addition to many accidents, they were recurring annually. This was followed by sawmill and manufacture of laminated wood and plywood, pressed and agglomerated sheets.

Exposure of workers to accidents is due to the existence of activities that take place in the midst of a work environment that do not comply with safe and ergonomic working conditions. Fiedler et al. (2010) when analyzing working conditions in the joinery industry in the southern state of Espírito Santo, Brazil, discovered that in the unanimous opinion of workers, their functions were dangerous and accompianed by high risks, with $66 \%$ of the employees already having experienced accidents, which required a period of four days to two months for recovery.

By comparing the variables of the work environment measured in the wood production unit and the permissible levels for the workday, it is possible to analyze whether the activity is healthy. Thus, Brazilian Standard NR 17 (2012), that deals with ergonomics, aims to establish parameters that allow working conditions to to be adapted to the psychophysiological characteristics of workers, to provide comfort, safety and health.

An unhealthy or dangerous work environment is likely to be the principal reasons for the high rate of accidents in wood production. Guimarães et al. (2018) measured the variables thermal comfort, wind speed, illuminance and noise for a factory of production of forest tools with wood handles, and concluded that the activity occurred in thermal discomfort in the afternoon shift, with wind speeds below $0.75 \mathrm{~m} / \mathrm{s}$, poor illuminance and noise, medium, above what is tolerated for an eight-hour workday and without hearing protection. A simple and

FLORESTA, Curitiba, PR, v. 51, n. 2, p. 339-345, abril/jun 2021.

Guimarães, P. P. et.al.

ISSN eletrônico 1982-4688

DOI: $10.5380 /$ rf.v51 i2. 68268 
inexpensive way to prevent accidents at work without reducing productivity is to issue personal protective equipament (PPE) to employees, while also reinforcing safety during operation (HEGEDUS et al., 2011).

Unregistered accidents, that is unreported accidents, prevent the victim from being able to prove that it was due to their work environment, which could be verified later by medical experts. For wood manufacture, $21.3 \%$ of accidents at work were not reported. This means that for every accident, a quarter was not officially recorded. Therefore for each sub-sector in wood product manufacturing, these values are even higher (Table 2). The furniture manufacturing resulted in the largest number of work-related accidents in wood product manufacturing, and still had $27.3 \%$ of its accident occurrences not reported.

Among the accidents recorded in wood production, the main type was typical accidents, being presented by more than $84.4 \%$ of the occurrences of accidents (furniture production), Table 3 . The large number of typical accidents in wood production demonstrated a greater need to allocate more care and time regarding training and retraining of workers involved in these activities.

Typical accidents can occur when the anthropometric characteristics of the workers are different from the dimensions of the tools, machines and equipment used in the work environment. When analyzing the anthropometry of carpentry workers in Espírito Santo State, Brazil and their relationship with the machinery involved, Guimarães et al (2016) concluded that all benches were lower than the recommended height limit, and that the saws used were kept higher than the maximum height of the workers creating a typical accident hazard to them.

When analyzing the layout of the joinery operation in the south of Espírito Santo, Brazil Fiedler et al. (2009) confirmed that an aggravating factor for the occurrence of accidents was the improper positioning of some machines (layout), being close to places of intense movement and hindering the movement with the parts, in addition to factors of the structure itself, such as the presence of pilasters and waste in the work area, and uneven floors.

The typical accidents occurred in the first, second or eighth hour in the work shift, for the cross-cutting activity in the wood products industry in Paraná State, and the profile of the victim was young, male and married (RIBEIRO et al., 2009). For the wood products industry in Lages, Santa Catarina State, the main incedences of injuries that occurred were contact with the moving saw, objects or parts that had fallen from moving machines, falling down of the worker or over-exersion from lifting or pushing an object (SOUZA et al., 2002).

For every 100 wood production workers, 9.5 may have an accident on the way from their home to the place of work or vice versa. When assessing commuting accidents related to furniture manufacturing, this percentage rises to $12.7 \%$. The low percentage of commuting accidents was due to the companies' policies allowing their workers to travel in public transportation and under the contractor's responsibility.

In relation to occupational diseases, the activities with the highest occurrences were the manufacture of furniture and sawmill work. The method of diagnosis for occupational disease was through medical examinations and it was according to the discretion of the occupational physician to request a Communication of Accidents at Work (CAT), which indicates the removal of the worker from risk exposure, and refers the worker to the National Institute of Social Security (INSS), which guides the injured worker in the adoption of prevention measures for their work environment (NR-7, 2012). The main diseases related to wood production activities were musculoskeletal diseases, hearing loss, dermatitis and mental illness. Sawdust was also a cause of sinusitis, asthma, bronchitis attacks and lung diseases (OLIVEIRA JUNIOR et al., 2014).

\section{CONCLUSION}

- The manufacturing of furniture showed an increasing rate in the number of direct jobs; however, this was also related to a higher number of total accidents that occurred, with more than $58.9 \%$ of total accidents.

- Wood product manufacturing brings together a set of dangerous activities with a high number of accidents and, therefore, deserves greater attention to mitigate these issues. The activities of sawmill and manufacture of laminated wood and sheets, shows a reduction in the rate of direct jobs also in number of total accidents. Even so, it still presents a high rate of accident incidence.

- In addition to the higher number of occupational accidents, there is a variation in unregistered accidents from 17.8 to $29.7 \%$. Many of these unreported cases can conceal the actual work-place safety situation in wood product manufacturing.

\section{REFERENCES}

AlMEIDA, A. N.; SANTOS, A. J.; SILVA, J. C. G. L.; BITTENCOURT, A. M. Análise do mercado dos principais produtos não-madeiráveis do estado do Paraná. Floresta, Curitiba, v.39, n.4, p.753-763, 2009.

FLORESTA, Curitiba, PR, v. 51, n. 2, p. 339-345, abril/jun 2021.

Guimarães, P. P. et.al.

ISSN eletrônico 1982-4688

DOI: $10.5380 /$ rf.v51 i2. 68268 
AGUIAR, G. P.; ROCHA, J. D. S.; SANTOS, A. J.; SILVA, J. C. G. L.; HOEFLICH, V. A. Comportamento do mercado dos principais produtos florestais não-madeireiros da região nordeste do Brasil. Enciclopédia Biosfera, Goiânia, v. 10, n. 18, p. 983-992, 2014.

ANUÁRIO ESTATÍSTICO DA ASSOCIAÇÃO BRASILEIRA DE PRODUTORES DE FLORESTAS PLANTADAS - ABRAF, 2013. Avaliable in: < https://www.ipef.br/estatisticas/relatorios/anuario-ABRAF13BR.pdf> Accessed in: <28/08/2019>.

ASSUNÇÃO, A. A.; CAMARA, G. R. A precarização do trabalho e a produção de acidentes na colheita de árvores. Caderno CNH. Salvador. V. 24, n. 62, p. 385-396, 2011

FIEDLER, N. C.; GUIMARAES, P. P.; ALVES, R. T.; WANDERLEY, F. B. Avaliação ergonômica do ambiente de trabalho em marcenarias no Sul do Espírito Santo. Revista Árvore. Viçosa, v. 34, n. 5, p. 907-915, 2010.

FIEDLER, N. C.; WANDERLEY, F. B.; NOGUEIRA, M.; OLIVEIRA, J. T. da S.; GUIMARAES, P. P.; ALVES, R. T. Adequação do layout de marcenarias no Sul do Espírito Santo baseado em parâmetros ergonômicos e de produtividade. Revista Árvore. Viçosa, v. 33, n.1, p. 161-170, 2009.

GUIMARAES, P. P.; BOTREL, R. T.; NOGUEIRA, N. W.; CASTRO, V. G. de; AGUIAR, G. P. de; CARMO, F. C. de A. Produtos florestais não madeireiros do nordeste brasileiro: carnaúba. Nativa. Sinop, v. 6, n. 2, p. 213218, 2018.

GUIMARAES, P. P.; FIELDER, N. C.; CARMO, F. C. de A.; GONÇALVES, S. B. Ergonomia em atividades florestais. Enciclopédia Biosfera. Goiânia, v. 1, n.1, p. 182-201, 2014.

GUIMARAES, P. P.; FIELDER, N. C.; CARMO, F. C. de A.; MORAES, F. de. Aplicações de variáveis antropométricas em postos de trabalho em marcenarias no Sul do Espírito Santo. Floresta. Curitiba, v. 46, n. 1, p. 11-20, 2016.

GUIMARAES, P. P.; FIELDER, N. C.; OLIVEIRA, J. T. de S.; LEITE, A. M. P.; LIMA, J. S. de S. Análise ergonômica do ambiente de trabalho na fabricação de ferramentas florestais. Ciência Florestal. Santa Maria, v. 28, n. 4, p. 1651-1665, 2018.

HEGEDUS, C. E. N.; MAZIERO, R.; TINTI, V. P.; DEMUNER, W. P. O uso de dispositivos de segurança alternativos para reduzir acidentes de trabalho na operação com serras nas indústrias madeireiras. Floresta e Ambiente. Seropédica, v. 18, n. 1, p. 60-68, 2011

INDÚSTRIA BRASILEIRA DE ÁRVORES (IBÁ). Sumário Executivo Ibá 2020. São Paulo: Ibá, 2020. 10p.

MEDEIROS, J. V.; JURADO, S. R. Acidentes de trabalho em madeireiras: uma revisão bibliográfica. Revista Agrogeoambiental. Pouso Alegre, v. 5, n. 2, p. 87-96, 2013

MENDOZA, Z. M. S. H.; BORGES, P. H. M. Segurança do trabalho em serrarias. Multitemas. Campo Grande, v. 21, n. 49, p. 113-139, 2016

NORMA REGULAMENTADORA - NR 7 - Programa de controle médico e de saúde ocupacional. In: Segurança e medicina do trabalho. 70 ed. São Paulo. Atlas, p. 83-97, 2012

NORMA REGULAMENTADORA - NR 17. Ergonomia. In: Segurança e Medicina do Trabalho. 70. ed. São Paulo: Atlas, p. 321-334, 2007.

NORMA REGUlamentAdORA - NR 31. Segurança e Saúde no Trabalho na Agricultura, Pecuária, Silvicultura, Exploração Florestal e Aquicultura. Avaliable in: < https://www.in.gov.br/en/web/dou/-/portarian-22.677-de-22-de-outubro-de-2020-285009351>. Accessed in <14-12/2020>

OLIVEIRA JUNIOR, E.; ALMEIDA, F. S. S.; MORRONE, L. C. Avaliação dos riscos de uma empresa de embalagens de madeira. Revista Laborativa. São Paulo, v. 3, n. 2, p. 41-55, 2014

RIBEIRO, S.; AUGUSTO, F. J. T.; KLUTHCOVSKY. Acidentes de trabalho na indústria madeireira de uma cidade do Paraná: Análise das Comunicações de Acidentes de Trabalho. Revista Salus. Guarapuava, v. 3, n. 1, p. 15-22, 2009

SAFETY AND HEALTH IN FOREST WORK: CODE OF PRACTICES OF ILO. Avaliable in: <http://www.fundacentro.gov.br/biblioteca/biblioteca-digital/publicacao/detalhe/2013/3/seguranca-e-saude-notrabalho-florestal>

FLORESTA, Curitiba, PR, v. 51, n. 2, p. 339-345, abril/jun 2021. 
SILVA, M. M. de S.; GONÇALVES, F. G.; FERRANO, A. C.; COSTA, C. C. da. Diagnóstico da empresas processadoras de madeira nas regiões Vale do Jequitinhonha e Centro Nordeste mineiro. Revista Científica Eletrônica de Engenharia Florestal. Garça, v. 17, n. 1, 2011.

SNIF BULLETIN 2017. Avaliable in: < http://www.florestal.gov.br/documentos/publicacoes/3230-boletim-snif2017-ed1-final/file> Accessed in: 30/08/2018.

SOCIAL SECURITY STATISTICAL YEARBOOK. Avaliable <http://www1.previdencia.gov.br/aeps2006/15_01_03.asp> Access in: 11/02/2021.

SOUSA, A. P.; VIANNA, H. A.; MINETTE, L. J.; MACHADO, C. C. Avaliação das condições de segurança do trabalho nos setores florestais de uma Instituição Federal de Ensino Superior. Revista Árvore. Viçosa, v. 34, n. 6, p. 1139-1145, 2010

ULTRAMARI, A. V.; SILVA, A. M. C.; PIGNATI, W. A. Ambiente de trabalho: influência da produção florestal sobre os acidentes do trabalho no Estado do Mato Grosso. Caderno de Saúde Coletiva. Rio de Janeiro, v. 20, n. 1, p. 25-31, 2012.

FLORESTA, Curitiba, PR, v. 51, n. 2, p. 339-345, abril/jun 2021. 